statute, it may be doubted that the courts are justified in so drastically limiting the arbitrator's function in the absence of new legislation. ${ }^{48}$

18 The Judicial Council of New York has suggested an amendment to $\$ 1448$ of the New York Civil Practice Act providing that a controversy cannot be arbitrated "when the controversy arises out of the performance of the contract and such performance has been rendered illegal or impossible by law." This suggested amendment would seem to limit by implication the power of the courts to stay arbitration despite an agreement to arbitrate to the cases specifically provided for. 17 Annual Rep., Judicial Council of New York, 225 (1951).

\title{
PROPRIETY OF COMMENT ON NON-TAXABILITY OF PERSONAL INJURY VERDICTS
}

Hall v. Chicago \& N.W. Ry. Co. ${ }^{1}$ raises a perplexing problem concerning the propriety of informing the jury that personal injury verdicts are not subject to federal income tax. ${ }^{2}$ Plaintiff brought suit under the Federal Employers' Liability $\mathrm{Act}^{3}$ to recover damages for permanent disability. During the trial the judge ruled in chambers that on the issue of earning capacity evidence of earnings before taxes should be presented. ${ }^{4}$ Although the trial resulted in a $\$ 50,000$ verdict for plaintiff, the trial court granted plaintiff's motion for a new trial, solely on the ground that it was prejudicial error for defendant's counsel to tell the jury that any award to the plaintiff would not be subject to federal income tax. The Illinois Appellate Court reversed and remanded the cause, with directions to reinstate the verdict.

In reaching the decision, the Appellate Court concerned itself primarily with the question of whether the defendant would be prejudiced if the jury assumed that the judgment was taxable. The court reasoned that if the jurors were not informed that the award was not taxable they might erroneously assume the contrary and increase it by an amount sufficient to offset the tax. The court concluded that it was desirable to inform the jury that the verdict would not be taxable in order to prevent such an unjustifiable windfall to the plaintiff. The court found support for its decision in a recent Missouri Supreme Court ${ }^{5}$ holding

1349 Ill. App. 175, 110 N.E. 2d 654 (1953).

2 Int. Rev. Code § 22(b)(5), 26 U.S.C.A. §22(b)(5) (1948).

345 U.S.C.A. $\$ \$ 51-60$ (1943).

4 This ruling is supported by the bulk of Anglo-American authority: Billingham v. Hughes, [1949] 1 K.B. 643, 9 A.L.R. 2d 311 (1949); Chicago \& N.W. Ry. Co. v. Curl, 178 F. 2d 497 (C,A. 8th, 1949); Stokes v. United States, 144 F. 2d 82 (C.A. 2d, 1944); Smith v. Pa. R. Co., 99 N.E. 2d 501 (1950). These cases hold that the trial court's refusal to allow evidence of plaintiff's net income after tax deductions was not reversible error, principally because such deductions are too conjectural and would involve insuperable difficulties in estimating the amount of income tax which the injured person would be liable to pay on his future earnings because of dependencies, outside income, and other considerations. But cf. De Vito v. United Airlines, 98 F. Supp. 88 (1951).

${ }^{5}$ Dempsey v. Thompson, - Mo. - 251 S.W. $2 \mathrm{~d} 42$ (1953), overruling Hilton v. Thompson, 360 Mo. 177, 227 S.W. 2 d 675 (1950). Criticizing Dempsey v. Thompson, see 33 B.U.I. Rev. 114 (1953), 32 Neb. L. Rev. 491 (1953). 
that it was error for the trial judge to deny defendant's request for an instruction informing the jury that no income tax would be assessed upon an award for personal injury.

In its decision the Appellate Court ignored the possibility that the plaintiff might be prejudiced by a comment to the jury that the award is tax free. Individual jurors, sensitive to tax burdens, might decide that since the plaintiff would have paid a tax on his income had he not been injured, he would be fully compensated by an award based on his net income. Such a result would be contrary to the measure of damages announced by the trial judge that only earnings before taxes should be considered.

It seems, therefore, that informing the jury that the award is taxable might well be prejudicial to the plaintiff, whereas withholding such information might prejudice the defendant. The resolution of this conflict depends upon a guess regarding the behavior of juries. Their behavior is so unpredictable that one may question the assumption underlying the decision of the Illinois Appellate Court, and the Missouri case relied upon, that the average juror would believe the award subject to income tax if not appraised to the contrary. The issue of income tax might never occur to the average juror, in which case there would be no possibility of prejudice to either party. Even if the jury believed the award taxable, there is some question as to whether itwould violate the judge's instructions and increase the award. If properly instructed the jury would be told to base its award exclusively on specifically enumerated items, e.g., loss of earnings, pain and suffering, and medical expenses. ${ }^{6}$ By the same token, it may be doubted that the jury would decrease an award simply because informed that it is not taxable. Given the inconclusiveness of speculations concerning the jury's response in this situation, a court might justifiably rely on the presumption that the jury follows the instructions of the court. ${ }^{7}$ In that event both parties would be adequately protected by proper instruction regarding the measure of damages without any reference to the taxability of the award. On the other hand, it may be urged that the conflict be resolved as follows: since the alternative possibilities of prejudice to either party are remote, or at least equal, the remark should be sanctioned simply because it is, after all, true. A court, of course, might be moved to accept this position if convinced that recent personal injury

oryou may consider (1) what evidence there is of the nature and extent of plaintiff's injuries... (2) the physical disability of the plaintiff resulting from such injury ... (3) the physical pain and suffering plaintiff has suffered as a direct and proximate result of such alleged injuries.... (4) the loss of earnings." Hall v. Chicago \& N.W. Ry. Co., 349 Ill. App. 175,110 N.E. 2d 654 (1953), Abstract of Record \#45920, Instruction 5, p. 311;"Both the questions of liability and damages are matters to be determined from evidence and under the instructions of the court. Prejudice, sympathy or any outside matters should not affect your judgment." Ibid., at Instruction 30, p. 326.

'Marder, Luce \& Co. v. Leary, 137 III. 319, 26 N.E. 1093 (1891) (there would be no purpose in giving a jury instructions in any case if it is to be assumed that the jurors do not follow them); Devine v. Chicago City R. Co., 167 Ill. App. 351 (1912); Brant v. Chicago \& A. R. Co., 294 Ill. 606, 128 N.E. 732 (1920). 
awards have been too large. Although this factor is one of doubtful relevancy, it seems to have moved the court in the Hall case. ${ }^{8}$

Such a result invites consideration of other situations in which the controlling standard of tort damages is sought to be supplemented under the guise of selfprotection. Indeed it was urged by the plaintiff that the rule that he is not entitled to have his award increased to cover attorney's fees and costs established the general proposition that the disposition of the award, once it reached the hands of the plaintiff, should not enter into the jury's calculation. It might follow from such a principle that the fact that the plaintiff does not have to dispose of a part of the award-for payment of income tax-should also not be considered. The issue of attorney's fees is clearly distinguishable, however, since the commenting party seeks only to prejudice the other party and not to protect some legitimate interest of his own. ${ }^{9} \mathrm{~A}$ more telling analogy may be made to the exclusionary rule concerning insurance. Defendant's counsel is not permitted to inform the jury that the defendant is uninsured ${ }^{10}$ despite the possibility that the jury might otherwise assume insurance and find liability or increased damages because of its notions of desirable risk distribution. Likewise prohibited are attempts to infiltrate the issue of the financial status of the parties ${ }^{11}$ by a comment to the effect that the affluence of the parties should not be taken as an index of credibility.

A parade of such examples might convince a court to exclude a comment justified as relevant on the assumption that the jury will fail to comply with its express instructions.

${ }^{8}$ The court quotes with seeming approval a portion of the opinion in Wetherbee v. Elgin, Joliet \& Eastern Ry. Co., 191 F. 2d 302, 309 (C.A. 7th, 1951): "The way the amounts awarded in verdicts in personal injury cases have been rapidly increasing is a matter of concern to all who are interested in a fair and orderly administration of justice."

${ }^{\circ}$ Counts v. Thompson, 359 Mo. 485, 222 S.W. 2d 487 (1949) (amount of fee plaintiff's attorney is to receive in action for injury under F.E.L.A. should not be considered by the jury in determining the amount of damages). Washburn v. Burke, 84 Ill. App. 587 (1899); Oelrichs v. Spain, 15 Wall. (U.S.) 211 (1872); Ritter v. Ritter, 381 Ill. 549, 46 N.E. 2d 41 (1943).

${ }^{10}$ In most American jurisdictions it is reversible error to admit evidence that defendant is insured and that the loss will fall upon an insurance company. Accord: Rodzborskin v. American Sugar Refining Co. of New York, 104 N.E. 616 (1914); 2 Wigmore, Evidence $\$ 282$ (a) (1940); 25 Mich. L. Rev. 208 (1926); William v. Tourrangeau, 116 Vt. 199, 77 A. 2d 565 (1950) (where defendant attempted to prove lack of coverage, evidence held improperly admitted); 4 A.L.R. 2d 748, 761 (1949) (note on general topic).

u Herstein v. Kemker, 19 Tenn. App. 681, 94 S.W. $2 d 76$ (1935) (after ruling that evidence of pecuniary condition of both plaintiff and defendant was incompetent on damage issue, defense attorney had duty to abide by ruling and refrain from statement in jury's presence which directly or inferentially called attention to such matters); Weave v. Shell Oil Co., 129 Cal. App. 232, 18 P. 2d 36 (1933) (where plaintiff's counsel stated defendant was great rich corporation, new trial properly granted); Goldstein v. New York, 111 N.Y.S. 2d 615 (1952) (counsel's remark that city was rich and had made provisions for paying such claims was improper); De Rosseau v. Chicago St. P. \& M. Ry. Co., 256 Wis. 19, 39 N.W. 678 (1949) (improper appeal to prejudice because of wealth of a party sufficient ground for a new trial). 